УДК 373.5.016:30]:004.9

Гриценчук Олена Олександрівна

науковий співробітник Інформаційно-аналітичного відділу педагогічних інновацій Інститут інформаційних технологій і засобів навчання НАПН України, м.Київ, Україна gritsenchuk@iitta.gov.ua

\title{
ГЕНДЕРНИЙ ПІДХІД У МОНІТОРИНГОВИХ ДОСЛІДЖЕННЯХ ІК-КОМПЕТЕНТНОСТІ УЧНІВ В ОСВІТНІЙ ПРАКТИЦІ КРАЇН ЄВРОПИ
}

\begin{abstract}
Анотація. У статті проаналізовано гендерний підхід у моніторингових дослідженнях інформаційно-комунікаційної компетентності (ІК-компетентності) учнів загальноосвітніх навчальних закладів у країнах Свропи на сучасному етапі. Висвітлено результати досвіду таких міжнародних організацій як ООН, ЮНЕСКО, ЮНІСЕФ, Міжнародної асоціації оцінювання навчальних досягнень (The International Association for the Evaluation of Educational Achievement - IEA), Організації Економічного Співробітництва та Розвитку OECP (Organisation for Economic Cooperation and Development - OECD) щодо моніторингових досліджень ІК-компетентності учнів. Визначено особливості, загальні тенденції та перспективні шляхи розвитку.
\end{abstract}

Ключові слова: гендер; гендерний підхід; інформаційно-комунікаційна компетентність (ІК-компетентність) учнів; моніторинг ІК-компетентності; середня освіта.

\section{1. ВСТУП}

Постановка проблеми. Міжнародним співтовариством високо оцінюється роль інформаційно-комунікаційних технологій (ІКТ), як інструменту розвитку і соціальних перетворень. Сьогодні ІКТ є ознакою сучасної освіти, яка, зважаючи на це, має готувати молодь компетентною, зокрема, у галузі інформаційно-комунікаційних технологій. Формування і розвиток ІК-компетентності учнів є одним із питань, що має розв'язати освіта. ІКТ можуть дати поштовх до розвитку економічної, політичної та соціальної самостійності жінок і чоловіків, і тим самим, сприяти гендерній рівності, що визначено Організацією Об'єднаних Націй одним із показників рівня розвитку суспільства. Аналіз проблеми впровадження гендеру у моніторингові дослідження навчальних досягнень учнів в галузі ІКТ більш повно розкриває питання формування та розвитку ІК-компетентності учнів та окреслює шляхи для його вирішення. Вивчення міжнародного досвіду 3 даної проблеми може стати корисним для подальших досліджень і розвитку системи моніторингу якості освіти.

Аналіз останніх досліджень і публікацій. Проблему моніторингу якості освіти досліджували у своїх роботах Байназарова О.О, Бурда I.М., Свтух М.Б., Кремень В. Г., Локшина О.І., Луговий В.І., Лукіна Т.О, Ляшенко О. І., Ничкало Н.Г., Савченко О. Я., Сухомлинська О.В. [5], аспекти теорії і практики моніторингу рівня навчальних досягнень у галузі ІКТ грунтовно розглядалися у роботах Бикова В.Ю, Жука Ю. О., Морзе Н.В., Кузьминської, Овчарук О.В. та ін. [4; 6.]. Основні підходи до стандартизації інформаційно-комунікаційних компетентностей у системі загальної середньої освіти висвітлено у дослідженнях Бикова В.Ю., Богачкова Ю.М., Литвинової С.Г., Овчарук О.В., Паращенко Л.І., Пометун О.І., Спіріна О.М., Хуторського А.В. та ін. Розробкою питання гендерного підходу в інформаційному суспільстві займалися як зарубіжні так і вітчизняні вчені: Уолкер Н., Фонтейн М., Хефкен Дж., Віхор С.Т., Горошко, О.I., Чехайло I.I., Аккевинт М., Плимо Н. та ін. [2; 9.]. Деякі питання моніторингу ІК-компетентності учнів висвітлено недостатньо і потребують більш детального вивчення. 
Метою статті $є$ дослідження проблеми впровадження гендерного підходу у процес моніторингових досліджень ІК-компетентності учнів європейських країн.

\section{2. МЕТОДИ ДОСЛІДЖЕННЯ}

Дослідження проводилось в рамках науково-дослідної роботи «Формування інформаційно-комунікаційних компетентностей учнів у контексті євроінтеграційних процесів в освіті» Інституту інформаційних технологій і засобів навчання НАПН України. Основні методи, що застосовані у дослідженні: аналіз науково-педагогічної літератури, нормативно-правових міжнародних та вітчизняних документів, джерел, представлених в мережі Інтернет 3 проблем гендеру у процесі моніторингу IКкомпетентності учнів в європейських країнах, методи дослідження та узагальнення педагогічного досвіду.

\section{3. РЕЗУЛЬТАТИ ДОСЛІДЖЕННЯ}

Окреслюючи основні напрями розвитку вітчизняної освіти, провідні українські вчені визначають моніторинг, як один із інструментів оцінювання і управління якістю освіти. (Біла книга національної освіти України (проект), 2009 р.). [1] За визначенням Ляшенка О.І. під поняттям «моніторинг в освіті», розуміється «система заходів щодо збирання, опрацювання, аналізу та поширення інформації 3 метою вивчення i оцінювання стану функціонування певного об'єкта освітньої діяльності чи освітньої системи загалом та прогнозування їх розвитку на основі аналізу одержаних даних i виявлених тенденцій та закономірностей» $[5,26]$. Дослідник Локшина О.I. визначає моніторинг в освітній галузі як «систему збору, опрацювання й поширення інформації про діяльність освітньої системи, що забезпечує безперервне відстеження за ії станом і прогноз розвитку»[ 5,28$]$. Наведені визначення дають можливість в межах теми нашого дослідження з'ясувати, що до етапів моніторингу ІК-компетентності учнів відносяться: спостереження, збір даних, порівняння, а також оцінювання рівня навчальних досягнень учня в галузі ІКТ як результат діяльності освітньої системи. Проте, етапи інтерпретації, оприлюднення, розповсюдження та прогнозування результатів моніторингу використовують для надання рекомендацій щодо шляхів розвитку освітньої політики у напряму формування та розвитку ІК-компетентності учня.

Порівняльні дослідження навчальних досягнень учнів в галузі ІКТ відбуваються за різними показниками, одним із яких є гендер. Гендер (англ. gender - «стать», від лат. genus - «рід») - соціально-біологічна характеристика, через яку визначаються поняття «чоловік» і «жінка», психосоціальні, соціокультурні ролі чоловіка і жінки як особистостей, на відміну від статі, яка позначає біологічні відмінності. Світова спільнота опікується питанням гендерної рівності в умовах розвитку інформаційного суспільства. Впровадження гендерного підходу у ІКТ» $є$ процесом ідентифікації, оцінки та винищення гендерної нерівності у доступі і користуванні IКТ, а також адаптуванні ІКТ до специфічних потреб, обмежень і можливостей жінок і чоловіків. За визначенням ООН поняття "гендерний niдxid" це: "... процес оцінки будь-якого запланованого заходу $з$ точки зору його впливу на жінок і чоловіків, у тому числі законодавства, стратегій і програм в усіх областях і на всіх рівнях. Справжня стратегія грунтується на тому, щоб інтереси і досвід жінок, так само як і чоловіків, стали невід'ємним критерієм при розробці загальної концепції, при здійсненні, моніторингу i оцінювання загальних напрямків діяльності та програм у всіх політичних, економічних і суспільних сферах з тим, щоб і жінки і чоловіки могли одержувати рівну вигоду, а нерівність ніколи не вкорінювалася б" [8]. Впровадження гендерних підходів $€$ 
питанням соціальної справедливості, зокрема, необхідною умовою для забезпечення рівного доступу до ІКТ.

Визначальною подією для світового співтовариства у сенсі розуміння IКТ як потужної сили, що спроможна посприяти гендерній рівності, була IV Bсесвітня конференція із становища жінок «Дії в інтересах рівності, розвитку та миру», яка пройшла у Пекін у 1995 році. Актуальні питання щодо ІКТ та ролі і місця жінок у інформаційному суспільстві, що обговорювалися на конференції, хоч і не входили у основну програму заходу, адже заклали підгрунтя для подальших дієвих кроків подолання гендерного розриву. Наступні роки було позначено міжнародними ініціативами, що окреслювали шляхи для вирішення проблеми гендерної нерівності, а саме: запровадження ЮНЕСКО програмного напряму «Жінки i засоби масової інформації» та реалізація проектів «Жінки, що працюють у мережі», «Жінки, що розмовляють $з$ жінками: жіноче місцеве сільське радіо у найменш розвинутих країнах» (1996р.), реалізація проекту «Принципи, що визначають політику щодо статі, партнерства і розвитку ІКТ» (1997р.) та ін. Темою двадцять третьої спеціальної сесії Генеральної Асамблеї ООН стала тема «Жінки у 2000 році: рівність між чоловіками і жінками, розвиток у XXI столітті миру». У 2010 р. Генеральною асамблеєю ООН створено UN Women (United Nations Entity for Gender Equality and the Empowerment of Women) - підрозділ ООН з питань гендерної рівності і розширення прав і можливостей жінок, що об'єднав чотири структурних одиниці організації, а саме: Жіночий Фонд ООН ЮНІФЕМ (United Nations Development Fund for Women — UNIFEM); Відділ 3 поліпшення становища жінок (Division for the Advancement of Women - DAW); Міжнародний дослідницький та навчальний інститут щодо поліпшення становища жінок (International Research and Training Institute for the Advancement of Women INSTRAW); Канцелярію Спеціального радника 3 гендерних питань та поліпшення становища жінок (Office of the Special Adviser on Gender Issues and Advancement of Women - OSAGI).

Приховані й відкриті елементи статевої дискримінації в дидактичних програмах шкіл різних країн світу визначаються ЮНЕСКО. Проблема врахування гендерної складової у освітньому процесі досліджується як зарубіжною, так і вітчизняною педагогічною спільнотою. На думку дослідниці Н.Прімо сприяння включенню гендерного аналізу у процес навчання у галузі IKT, координування та розповсюдження матеріалів і досвіду роботи має важливе значення для освіти [13].

Міжнародні організації, що проводять моніторинг навчальних досягнень учнів, використовують гендерній підхід в процесі дослідження. Так у пілотному дослідженні, що проводилося Міжнародною асоціацією оцінювання навчальних досягнень (IEA The International Association for the Evaluation of Educational Achievement), одним із індикаторів був гендерний показник. Країнами, що взяли участь у моніторингу були: Англія, Бельгія, Ізраїль, Польща, США, Федеративна республіка Німеччина, Фінляндія, Франція, Швейцарія, Швеція, Шотландія, Югославія. Досліджувалися навчальні досягнення учнів 13-річного віку. Опубліковані дані щодо результатів моніторингу за 1960 рік, свідчили, що найменшим, за гендерним показником, розривом у досягнутому рівні навчальних досягнень виявився розрив у Швеції та Шотландії, а найбільшим - у Польщі, Німеччині і Бельгії. У США дівчатка були успішніші за хлопців з усіх предметів. В інших країнах результати дівчаток були успішними у процесі моніторингу невербальних навичок, читання й математики, хлопців - у хімії, фізиці, біології та географіï [10].

Першим моніторинговим дослідженням, що проводила IEA у галузі IKT, було дослідження «Комп'ютери у освіті» - COMPED (Computers in Education Study, 1989 р.). Вивчалися знання, вміння, навички і ставлення щодо впровадження комп'ютера у 
навчальній процес. Результати дослідження свідчили, що у більшості країн-учасниць користувачами комп'ютеру у школі були представники чоловічої статі. За висновком, зробленим дослідницею Бетті Колліс, існував гендерній розрив між знаннями, уміннями, навичками та особистісним ставленням учнів, що використовують комп'ютер у навчанні, і особливо він виявився у середній ланці шкільного освіти. Аналіз результатів моніторингу засвідчив, що лише франкомовні країни та Греція впроваджували гендерно-спрямовану політику IKT в освіті. Зокрема, набув актуальності напрям комп'ютерної освіти для вчителів-жінок та напрям підготовки серед вчителів-жінок координаторів 3 IKT у школах. Спеціальності у галузі інформаційно-комунікаційних технологій традиційно опановували вчителі-чоловіки. Цей досвід був корисним, враховуючи, що основний кадровий склад шкільних вчителів - представниці жіночої статі.

Організація Економічного Співробітництва та Розвитку - OECP (Organisation for Economic Co-operation and Development - OECD) реалізує Програму оцінки навчальних досягнень учнів PISA (Programme for International Student Assessment - PISA). Напрями моніторингу Програми не фокусуються на вимірюванні рівня знань і навичок у галузі IКТ, однак слід відзначити загальний підхід до розуміння важливості вивчення i висвітлення спектру проблем, які стосуються впровадження інформаційнокомунікаційних технологій у освіту для навчання впродовж життя, що відображено у аналітичних документах, звітах і дослідженнях.

Сьогодні, коли розвиток сучасної освіти відбувається на засадах компетентнісного підходу, до складової поняття як природничої, так і математичної компетентності також належать навички використання сучасних технічних засобів, пов'язаних з інформаційними і комунікаційними технологіями; грамотність читання стосується грамотності читання друкованих і цифрових текстів, визначена PISA об’ єктом дослідження, та розуміється як «зацікавленість учня, його особисте ставлення та здібності щодо використання цифрових технологій і засобів комунікації, можливість доступу, керування, інтегрування та розвитку інформації, набуття нових знань i співпраці із іншими членами суспільства 3 метою ефективної участі у житті суспільства» [3].

Формування i розвиток ІК-компетентності може відбуватися як в межах відповідного предмету галузі ІКТ, так і у процесі навчання іншим дисциплінам. Відповідно, порівняльні дослідження моніторингу ІК-компетентності учнів можуть бути складовою частиною моніторингу з будь-якого предмету. За результатами міжнародної Програми оцінки навчальних досягнень учнів було підготовлено аналітичний звіт «PISA 2009: учні онлайн», присвячений використанню цифрових технологій у навчанні з врахуванням гендерного підходу. Дослідження, у якому брали участь 19 країн, висвітлило існування розриву у продуктивності цифрового читання між хлопчиками і дівчатками [12].

Діаграма «Якими є навички дівчат і хлопців цифровому читанні?» (Діаграма.1.) демонструє результати навчальних досягнень учнів у роботі із цифровими текстами ранжовані за п'ятьма рівнями. Ліворуч - результати навчальних досягнень хлопчиків, праворуч - дівчаток. На кожному з п'яти рівнів помітне відставання хлопчиків. Така ситуація викликала хвилювання експертів програми і змусила шукати відповідь, що допомогла б пояснити причину такої розбіжності. Крім електронного читання, досліджувалося паперове читання, де дівчатка також виявили більш високі результати. Саме $з$ цим експерти пов'язують розрив у показниках хлопців і дівчат у електронному читанні і письмі. 
How proficient are girls and boys in digital reading?

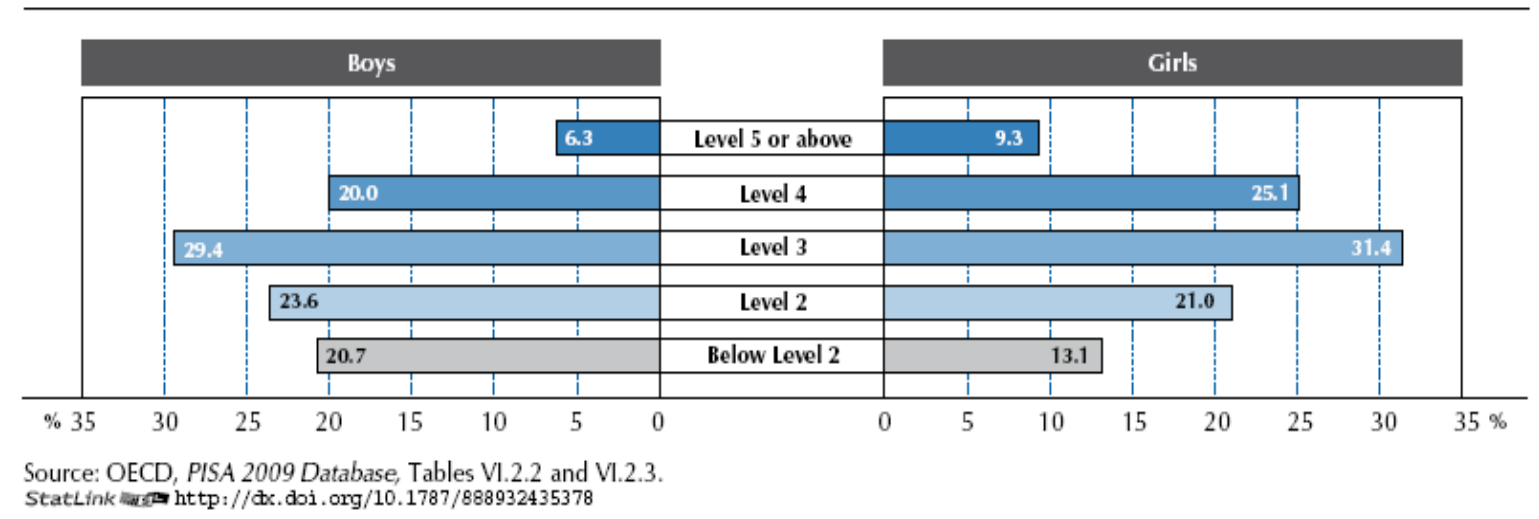

Діаграма 1. Якими є навички дівчат і хлопщฺів у циифровому читанні?

Аналіз і узагальнення міжнародного досвіду дозволяє зробити висновок про достатньо високий потенціал щодо набуття знань умінь і навичок і розвитку ІКкомпетентності представницями жіночої статі. Постає питання: чи мають дівчата і хлопці рівні можливості для подальшого навчання і реалізації і розвитку у дорослому житті, набувши ІК-компетентності? Свропейська комісія спільно 3 Eurostst (Статистичне бюро Свропейського Союзу) та EURIDCE (Інформаційна мережа з освіти в Європі) інформує міжнародну спільноту про стан і тенденції розвитку освітніх систем, публікуючи щорічні збірники «Основні дані про Свропу» (Key Data on in Europe). За даними «Key Data on Education in Europe 2012» у період 2000-2009 років у середньому в країнах ЄС-27, у 2009 році у країнах Свропейського Союзу, в середньому, 124 жінок було зараховано до вищих навчальних закладів на кожні 100 чоловіків. 3 2000 року кількість жінок-студенток збільшилася майже на 10\% [14].

За даними обстеження, що проводило Евростат щодо використання IКТ у віковій категорії від 16 до 24 років, гендерний розрив у користуванні комп'ютером, мережею Інтернет та володінні навичками у галузі ІКТ не значний і складає близько 5\%. Юнаки і дівчата використовують Інтернет з різною метою. Протягом обстеження, що проходило 3 місяці, серед респондентів найбільша активність була позначена у комунікативній діяльності, 74\% дівчат і 72\% юнаків використовували Інтренет головним чином для електронного спілкування. Кількість юнаків вдвічі перевищувала кількість дівчат при завантаженні програмного забезпечення: $38 \%$ юнаків порівняно $318 \%$ дівчат. Юнаки частіше завантажували музику та ігри: 56\% юнаків порівняно з 39\% дівчат. Разом 3 цим, дівчата активніше використовували мережею Інтерент 3 метою освіти: 31-32\% дівчат і 27\% юнаків. Источник: Евростат, Жизнь женщин и мужчин в Европе статистический портрет, Люксембург ЕС, 2008 г.

Міжнародний союз електрозв'язку (ITU - International Telecommunication Union) також проводить масштабні дослідження. За даними станом на 2008-2010 роки, загалом кількість жінок, що користуються Інтернет, була меншою за кількість користувачівчоловіків. (Діаграма 2.) [7] 
Percentage of Internet users, by gender, European countries latest available year (2008-2010)

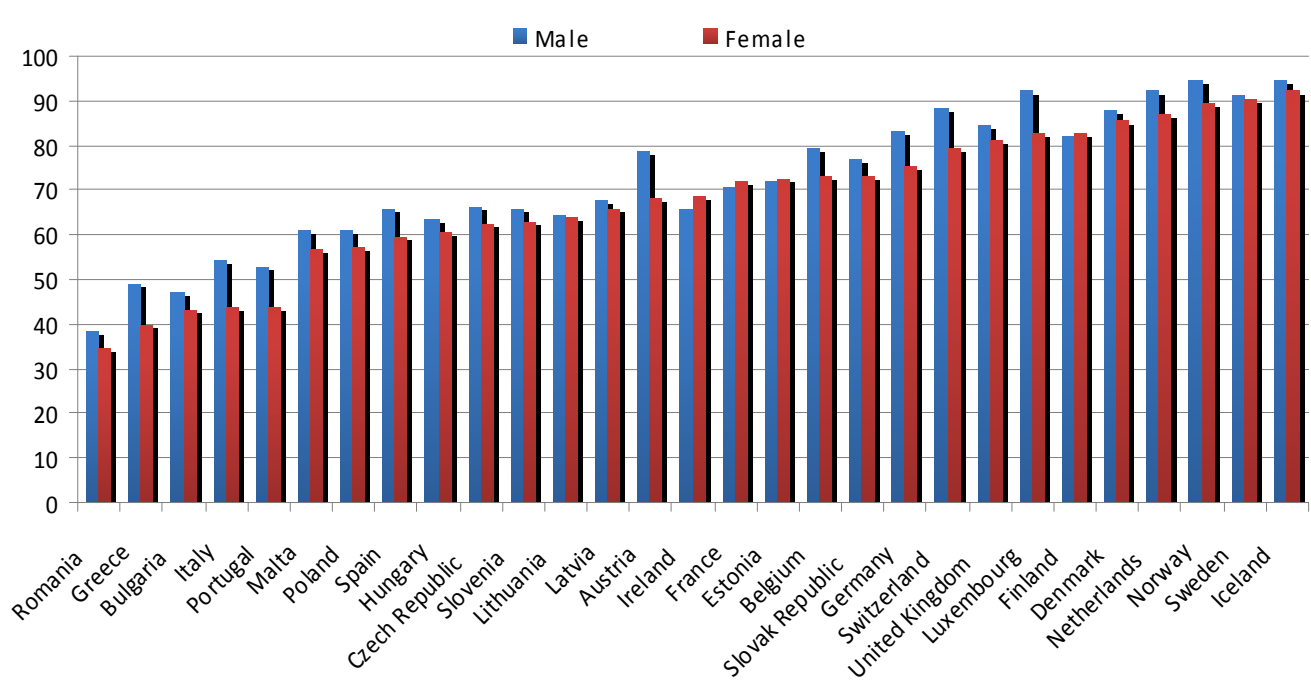

Діаграма 2. Відсоток користувачів мережею Інтернет, за гендером, краӥни Свропи на поточний період (2008-2010)

Серед 29 країн Європи (діаграма. 3) [7] практично однаковий відсоток користувачів-чоловіків і користувачок-жінок у Естонії, Литві, Фінляндії, Франції та Швеції. У Естонії, Ірландії, Фінляндії, Франції кількість жінок незначно, але переважає. Дещо нижчі показники для інших 34 каїн світу, до складу яких входить Україна.

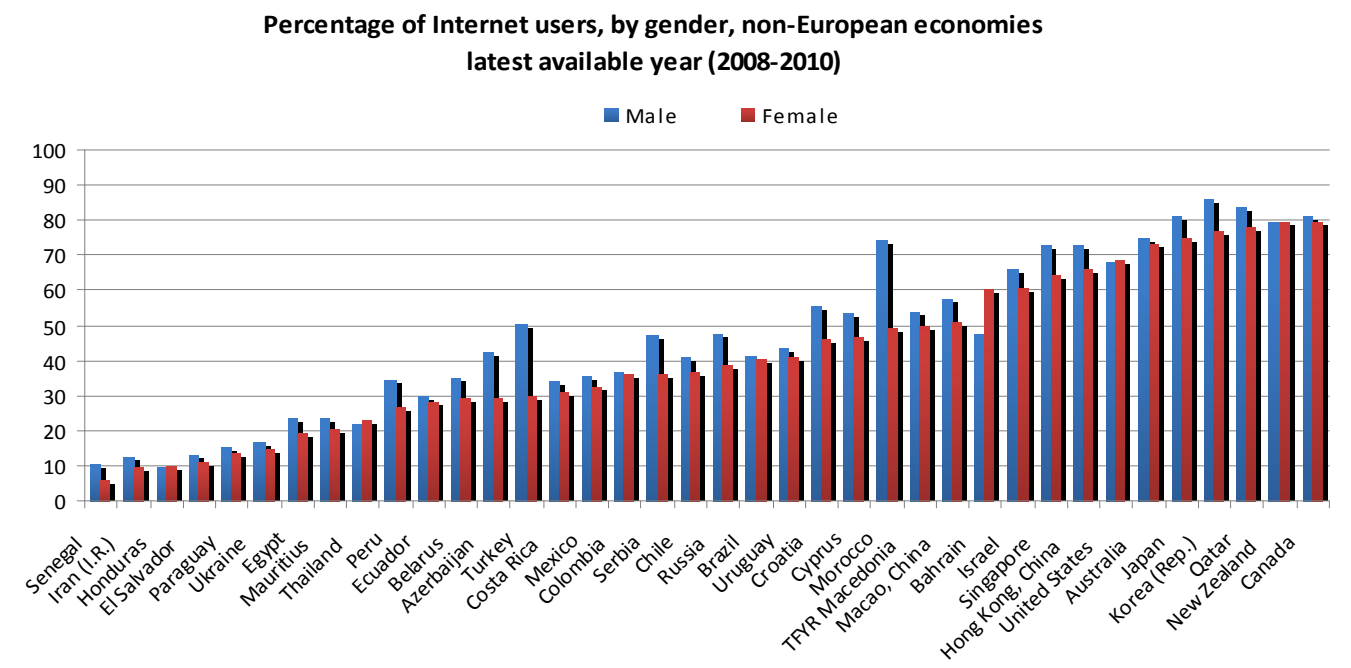

Діаграма 3. Відсоток користувачів мережею Інтернет, за гендером, неєвропейських краӥн на поточний період (2008-2010)

Слід зазначити також, що за результатами міжнародних досліджень відзначається специфіка використання Інтернету, а саме: жінки частіше користуються поштовими програмами, соціальними мережами, тематичними форумами і т.д., тоді коли чоловіки більше використовують Інтернет у професійних потребах. 


\section{4. ВИСНОВКИ ТА ПЕРСПЕКТИВИ ПОДАЛЬШИХ ДОСЛІДЖЕНЬ}

Узагальнюючи досвід міжнародних моніторингових та соціологічних досліджень, варто зазначити, що рівний доступ до якісної освіти надає рівні можливості жінкам i чоловікам щодо життя у сучасному інформаційному суспільстві. Поряд 3 цим, слід звернути увагу на певні суперечності, викликані гендерним розривом, що обмежують особистісний і професійний розвиток молоді.

Документом «Глобальні Цілі Розвитку Тисячоліття (ЦРТ) для досягнення до 2015 року» однією із восьми головних цілей окреслених для України, визначено заохочення гендерної рівності і розширення прав $і$ можливостей жінок, що визначає подальшу політику держави в усіх галузях життєдіяльності суспільства, зокрема, освітній.

За висновками експертів ООН, дане питання залишається відкритим і потребує подальшого розвитку. Включення гендерного компоненту до процесу формування політики системи освіти є одним із напрямів, що сприятиме його розв'язанню. Створення гендерно збалансованого інформаційного простору - один із важливих напрямів освітньої політики.

Застосовування гендерного підходу під час моніторингових досліджень $\epsilon$ виключно важливим, через вплив на прийняття політичних рішень в галузі освіти, в тому числі і тих, що забезпечують підвищення рівня освіти та сприяння дотриманню рівних прав і можливостей жінок та чоловіків у галузі ІКТ для їх професійного, соціального та особистісного розвитку.

\section{СПИСОК ВИКОРИСТАНИХ ДЖЕРЕЛ}

1. Біла книга національної освіти України / Акад. пед. наук України; за ред. В. Г. Кременя]. - К., 2009. - $185 \mathrm{c}$.

2. Вихор С.Т. Гендерне виховання учнів старшого підліткового та раннього юнацького віку: автореф. дис. на здобуття наук. ступеня канд. пед. наук: спец. 13.00.07 / С.Т. Вихор. - Тернопіль, 2006. -20 c.

3. Лукіна Т. О., Патрикеєва О. О. Моніторинг якості освіти: теорія та практика / Т. О. Лукіна, О. О.Патрикеєва // Відкрита педагогічна школа. - К.: Плеяди, 2005. - 111 с.

4. Моніторинг рівня навчальних досягнень з використанням інтернет-технологій: монографія / В.Ю. Биков, Ю.М. Богачков, Ю.О.Жук та ін.]. - К.: Пед. думка, 2008. - 127 с.

5. Моніторинг якості освіти: становлення та розвиток в Україні: Рекомендації з освітньої політики / Під заг. ред. О.І. Локшиної]. - К.: “К.І.С.”, 2004. - 160 с.

6. Морзе Н.В., Кузьмінська О.Г. Формування інформатичних компетентностей учнів середньої школи [Електронний ресурс] / Н.В.Морзе, О.Г. Кузьмінська // Інформаційні технологій і засоби навчання. - 2011 - №3 (23). - Режим доступу: http://journal.iitta.gov.ua/index.php/ittl/article/view/467 Заголовок з екрану.

7. ІКТ статистика за гендером [Електронний ресурс] // Веб-сайт Міжнародного союзу електрозв'язку (ITU - International Telecommunication Union. - Режим доступу: http://www.itu.int/ITUD/ict/statistics/Gender/index.html

8. Ниеманис А. Практическое руководство по внедрению внедрению гендерных подходов [Электронный ресурс] / Астрида Ниеманис //Официальный сайт Программы развития ООН. 2005. - Режим доступа: http://europeandcis.undp.org/news/show/67D3B291-F203-1EE9B97FC59F8884D24E

9. Fontaine M. A High-Tech Twist: ICT Access and the Gender Divide [Electronic resource]/ M.Fontaine // TechKnowLologia. - 2000 - Vol. 2, No. 2. - 2000. - Mode of access: www.techknowlogia.org

10. Foshay, A.W., Thorndike, R.L., Hotyat, F., Pidgeon, D.A., Walker, D.A. Educational achievements of thirteen-year-olds in twelve countries: Results of an international research project, 1959-1961 [Electronic resource] / A.W.Foshay, R.L.Thorndike, F.Hotyat, D.A.Pidgeon, D.A.Walker// Hamburg: UNESCO Institute for Education. - 1962. http://unesdoc.unesco.org/images/0013/001314/131437eo.pdf

11. Knowledge and skills for life. First results from ODCE programme for international student assessment PISA 2000, 2001. 
12. PISA 2009 Results: Students on Line: Digital Technologies and Performance [Electronic resource] // OECD. - 2011. - Mode of access: http://dx.doi.org/10.1787/9789264112995-en

13. Primo N. Gender issues in the information society [Electronic resource] / Natasha Primo // UNESCO Publications for the World Summit on the Information Society. - 2003 - Режим доступу: http://portal.unesco.org/ci/en/file_download.php/250561f24133814c18284feedc30bb5egender_issues.pdf

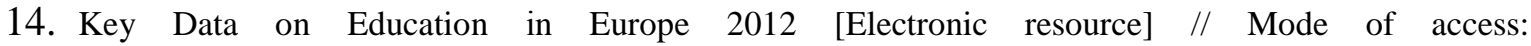
http://uk.wikipedia.org/wiki/\%D2\%90\%D0\%B5\%D0\%BD\%D0\%B4\%D0\%B5\%D1\%80

Матеріал надійшов до редакиії 17.10.2013p.

\title{
ГЕНДЕРНЫЙ ПОДХОД В МОНИТОРИНГОВЫХ ИССЛЕДОВАНИЯХ ИК-КОМПЕТЕНТНОСТИ УЧАЩИХСЯ В ОБРАЗОВАТЕЛЬНОЙ ПРАКТИКЕ СТРАН ЕВРОПЫ
}

\author{
Гриценчук Елена Александровна \\ научный сотрудник Информационно-аналитического отдела педагогических инноваций \\ Институт информационных технологий и средств обучения НАПН Украины, г. Киев, Украина \\ gritsenchuk@iitta.gov.ua
}

\begin{abstract}
Аннотация. В статье проанализирован гендерный подход в мониторинговых исследованиях информационно-коммуникационной компетентности (ИК-компетентности) учащихся общеобразовательных учебных заведений в странах Европы на современном этапе. Освещены результаты исследования зарубежного опыта международных организаций ООН, ЮНЕСКО, ЮНИСЕФ, Международной ассоциации оценивания учебных достижений (The International Association for the Evaluation of Educational Achievement - IEA), Организации Экономического Сотрудничества и Развития ОЕСР (Organisation for Economic Cooperation and Development - OECD) по мониторинговым исследованиям ИК-компетентностей учащихся. Определены особенности, общие тенденции и перспективные пути развития.
\end{abstract}

Ключевые слова: гендер; гендерный подход; информационно-коммуникационная компетентность (ИК-компетентность) учащихся; мониторинг; общее среднее образование.

\section{GENDER APPROACH IN MONITORING STUDIES OF PUPILS' IC-COMPETENCE IN EDUCATIONAL PRACTICE IN EUROPE}

\section{Olena O. Grytsenchuk}

researcher of the Informational and analytical department for pedagogical innovations Institute of Information Technologies and Learning Tools of the NAPS of Ukraine, Kyiv, Ukraine gritsenchuk@iitta.gov.ua

\begin{abstract}
The article deals with the analysis of gender issues in monitoring studies of students' information and communication competence ( IC-competencies) in european secondary schools at the present stage. There are highlighted the results of research of experience of international organizations, such as: UNDP, UNESCO, UNISEF, The International Association for the Evaluation of Educational Achievement - IEA, Organisation for Economic Co-operation and Development - OECD) on monitoring studies of students' IC-competencies. There are identified peculiarities, common trends and future development.
\end{abstract}

Keywords: gender; gender approach; information and communication competence (ICcompetence) pupils; quality monitoring; general secondary education.

REFERENCES (TRANSLATED AND TRANSLITERATED) 
1. White Paper of National Education of Ukraine / Acad. ped. Sciences of Ukraine, ed. VG Kremen ]. - K. 2009. - 185 c. (in Ukrainian)

2. Vyhor S.T. Gender education students older teenage and early adolescence: Author. Thesis. for the sciences. degree candidate. ped. sciences specials. 13.00.07 / ST Whirl. - Ternopil, 2006. - 20 p. (in Ukrainian)

3. Lukina T.O., Patrikeev A.A. Quality of Monitoring Education: Theory and Practice / T. O. Lukina, A.A. Patrykeyeva // Open School teacher. - Kyiv: The Pleiades, 2005. - 111 p. (in Ukrainian)

4. Monitoring the evaluation of educational achievement using Internet technologies: monograph / V. Bykov, Y. Bohachkov, Yu.O.Zhuk et al.]. - K. Ped. view, 2008. - 127. (in Ukrainian)

5. Monitoring Education Quality Development in Ukraine: Educational Policy Recommendations / O.I. Lokshina ]. - K.: " KIS ", 2004. - 160 p. (in Ukrainian)

6. Morse N.V., Kuzminska O.H. Formation informatyc competencies high school students [online] / N.V.Morze , O.H. Kuzminska // Information technology and learning tools. - 2011 - № 3 (23). - Available from: http://journal.iitta.gov.ua/index.php/itlt/article/view/467 - Title of the screen. (in Ukrainian)

7. ICT statistics by gender [online] // Website of the International Telecommunication Union. - Available from: http://www.itu.int/ITU-D/ict/statistics/Gender/index. html (in Ukrainian)

8. Niemanis A. How to implement gender mainstreaming [online] / Astrid Niemanis // Official site of the UN Development Programme. - 2005. - Available from: http://europeandcis.undp.org/news/show/67D3B291-F203-1EE9-B97FC59F8884D24E (in Russian)

9. Fontaine M. A High-Tech Twist: ICT Access and the Gender Divide [online] / M.Fontaine // TechKnowLologia. - 2000 - Vol. 2, No. 2. - 2000. - Available from: www.techknowlogia.org (in English)

10. Foshay A.W., Thorndike R.L., Hotyat F., Pidgeon D.A., Walker D.A. Educational achievements of thirteen-year-olds in twelve countries: Results of an international research project, 1959-1961 [online] / A.W.Foshay, R.L.Thorndike, F.Hotyat, D.A.Pidgeon, D.A.Walker // Hamburg: UNESCO Institute for Education. - 1962. - Available from: http://unesdoc.unesco.org/images/0013/001314/131437eo.pdf (in English)

11. Knowledge and skills for life. First results from ODCE programme for international student assessment PISA 2000, [online] // OECD. - 2001. - Available from: http://dx.doi.org (in English)

12. PISA 2009 Results: Students on Line: Digital Technologies and Performance [online] // OECD. - 2011. Available from: http://dx.doi.org/10.1787/9789264112995-en (in English)

13. Primo N. Gender issues in the information society [online] / Natasha Primo // UNESCO Publications for the World Summit on the Information Society. - 2003. - Available from: http://portal.unesco.org/ci/en/file_download.php/250561f24133814c18284feedc30bb5egender_issu es.pdf (in English)

14. Key Data on Education in Europe 2012 [online]. - Available from: http://uk.wikipedia.org/wiki/\% D2\% $90 \%$ D0\% B5\% D0\% BD\% D0\% B4\% D0\% B5\% D1\% 80 (in English) 